\title{
International Completeness of Death Registration 2015-2019
}

\author{
Ariel Karlinsky ${ }^{1, \bigotimes}$ \\ ${ }^{1}$ Hebrew University, Jerusalem, Israel \\ ariel.karlinsky@mail.huji.ac.il
}

August 12, 2021

\begin{abstract}
Death registration completeness, the share of deaths captured by countries' vital registration systems, vary substantially across countries. Estimates of completeness, even recent ones, are outdated or contradictory for many countries. In this short paper, I utilize the annual amount of deaths registered in 139 vital registration systems around the world to provide the most up-to-date estimates of death-registration completeness from 2015 to 2019 .
\end{abstract}

\section{Introduction}

Countries, international organizations and civil society require up to date and reliable data in order to inform their decisions in all venues, especially in health matters. Without sufficient and well-understood data, the effect of policies and interventions cannot be understood properly. Moreover, for countries to understand if they are on the path to achieve many of the Sustainable Development Goals (UN, 2020) such as mortality reduction and fighting communicable diseases, reliable monitoring systems must be established and their performance tested. Indeed, this is recognized as goal 17.19.2 in the SDG (WHO, 2017):

By 2030, build on existing initiatives to develop measurements of progress on sustainable development that complement gross domestic product, and support statistical capacity-building in developing countries; Proportion of countries that (a) have conducted at least one population and housing census in the last 10 years; and (b) have achieved 100 per cent birth registration and 80 per cent death registration.

WHO (2017) further emphasizes that the preferred source to check progress of 17.19.2 is "Civil Vital Registration Systems", followed by Censuses. The recent SCORE assessment tools (WHO, 2021) further emphasized this by including "Full Birth And Death Registration" as one of it's main indicators.

The completeness of death registration is estimated by dividing the number of registered deaths in a given period (such as year) by the number of expected deaths, as predicted by the countries' demographic and socioeconomic properties. The most prominent sources for the number of expected annual deaths are United Nations (2019) and GBD (2020) which utilize a wide variety of methods to estimate annual expected deaths for each country and year. Based on these sources, several studies have estimated the completeness of death registration (Mikkelsen et al., 2015; Adair and Lopez, 2018; GBD, 2020; UNSD, 2021; Johnson et al., 2021). However, some UNSD (2021) completeness's estimates are opaque, listed at "Less than $90 \%$ " (is it 40, 50 or $75 \%$ complete)? Additionally, even recent evaluations are outdated for some countries such as Bolivia, with UNSD (2021) estimate NOTE: This preprint reports new research that has not been certified by peer review and should not be used to guide clinical practice. from 2000, Adair and Lopez (2018); GBD (2020) from 2003 or, even if fairly recent, are before significant reforms 
such as Peru's SINADEF (Vargas-Herrera et al., 2018). Some of the completeness estimates are contradictory, with large differences between sources. For example, UNSD (2021) estimate the completeness of death registration in Lebanon from 2007 at "90\% or more" while GBD (2020) contains no estimate for it at all. ${ }^{1}$

This study utilizes the most recent mortality data from official sources for 139 between 2015 to 2019 to estimate the completeness of death registration in one single source.

\section{Data}

In this study, I utilize the World Mortality Dataset (Karlinsky and Kobak, 2021) which has collected weekly, monthly or quarterly death counts from 105 countries and territories between 2015 to 2021 . The counts from World Mortality Dataset (henceforth: WMD) are official counts published or provided by the relevant institutions in all countries: national statistics offices, civil registries, ministries of health, etc. A detailed list of sources for each country in WMD is available at https://github.com/akarlinsky/world_mortality. Inclusion criteria in WMD require some information to be available for 2020. As this paper focuses on the 2015-2019 period, data from WMD was supplemented by official reported number of deaths from 36 countries for this period, the countries are: Algeria, Bahamas, Bahrain, Belize, Bhutan, Botswana, Brunei, Cabo Verde, Dominican Republic, Eswatini, Fiji, Grenada, Guyana, India, Iraq, Ivory Coast, Jordan, Kenya, Kuwait, Lesotho, Maldives, Myanmar, Namibia, Nepal ${ }^{2}$, New Caledonia, Palestine, Rwanda, Saudi Arabia, Sri Lanka, Suriname, Trinidad and Tobago, Turkey, United Arab Emirates, Vietnam, Zambia, Zimbabwe. The sources for all additional countries are official reports from the relevant National Statistics Offices (henceforth referred to as NSOs), except for Kuwait for which the source is Alahmad et al. (2021), Zimbabwe (Stoneburner and Greenwell, 2017) and Eswatini for which the source is Khoza (2018). ${ }^{3}$ In order to find the relevant NSOs, I've used the lists maintained by the UN (https://unstats.un.org/home/nso_sites/), GHDX (http://ghdx.healthdata.org/), Centre for Excellence in CRVS (https://crvssystems.ca/country-profiles) and independent searches. The sources for the other countries are listed in the References section.

The annual amount of registered deaths in each country in 2015 to 2019 (See section 4 for countries without full 2015-2019 data) were merged with annual expected number of deaths from (United Nations, 2019), as based on the medium fertility variant for the same time period and the mean estimate of annual expected deaths from (GBD, 2020). The main advantage of GBD (2020) is that it includes estimates for countries with less than 500,000 people in 2019, which United Nations (2019) does not. For countries that exist in both, the final estimate for expected number of deaths in each year was obtained as the mean of the two estimates.

A few small changes were conducted in order to merge the two data sources: Karlinsky and Kobak (2021) data for South Africa is based on Bradshaw et al. (2021) which presented the expected number of deaths in 2020 based on information from 2018 to 2019, but without the raw data. Thus, the annual amount of registered deaths 2015 to 2018 was obtained from South Africa's NSO and not from Karlinsky and Kobak (2021). United Nations (2019) counts Transnistria and Kosovo as part of Moldova and Serbia, respectively while Karlinsky and Kobak (2021) has them separately. For this study, I joined them so that the completeness rate for Moldova and Serbia would not be downward-biased. ${ }^{4}$

\footnotetext{
${ }^{1}$ As shown in Appendix Table 9. "Underlying indicators for percent well-certified for data source with maximum percent well certified in each 5-year time interval for 204 countries, 1980-2019.7"

${ }^{2}$ Nepal vital registration information is provided in Nepali Calendar from 2072 to 2076, corresponding to April 2015 to April 2020. For this study I treated 2072 as 2015,2073 as 2016 and so on.

${ }^{3}$ Khoza (2018) is a news item referencing the official "Eswatini Annual Vital Statistics report". I was unable to locate the original official report myself as it seems to be only available in print.

${ }^{4}$ While this corrects for the data issue, the state issue remains. As Moldova exerts no de-facto control over Transnistria and Serbia over Kosovo, joining them together does not allow proper estimation of their completely independent vital registration systems.
} 


\section{Results}

The completeness rate for each country $c$ in year $t$ is defined as:

$$
\text { Completeness Rate }(\%)_{c, y}=\frac{\text { Registered Deaths }}{\text { Expected Deaths }}_{c, y}
$$

Table 1 shows the Completeness Rate for Death Registration in all 103 in the dataset, by year. The table, as well as underlying values for the number of registered and expected deaths, is available in a machine readable, longitudinal format at https://github.com/akarlinsky/death_registration. Figure 1 shows a map of the completeness rate in the latest available year for each country.

In comparison to previously reported estimates of death coverage, some of these are surprising. Albania is listed as "75-89\%" complete in UNSD (2021) and 71\% in GBD (2020). Here, I estimate it to be essentially 100\% complete. Algeria's also essentially complete, while UNSD (2021) and GBD (2020) estimate completeness at "Less than 90\%" and 31\% respectively and both estimates are outdated - from 2001 and 2006. Bolivia is estimated at almost 70\% complete, while UNSD (2021) and GBD (2020) estimate completeness at "Less than 90\%" and 47\%, respectively. Again, both estimates are outdated - from 2000 and 2003. Bhutan's vital statistics report for 2019, released on 2021, is the first one it issues, thus this is the first estimate of its' completeness completeness level that I'm aware of, which I estimate as $71 \%$ complete.

\begin{tabular}{lccccc}
\hline Country & 2015 & 2016 & 2017 & 2018 & 2019 \\
\hline Albania & $100 \%$ & $99 \%$ & $100 \%$ & $97 \%$ & $96 \%$ \\
Algeria & $98 \%$ & $95 \%$ & $98 \%$ & $98 \%$ & $98 \%$ \\
Andorra & $50 \%$ & $54 \%$ & $55 \%$ & $55 \%$ & $49 \%$ \\
Argentina & $100 \%$ & $100 \%$ & $99 \%$ & $98 \%$ & $98 \%$ \\
Armenia & $99 \%$ & $99 \%$ & $96 \%$ & $90 \%$ & $92 \%$ \\
Aruba & $75 \%$ & $85 \%$ & $75 \%$ & $75 \%$ & $68 \%$ \\
Australia & $90 \%$ & $88 \%$ & $89 \%$ & $84 \%$ & $85 \%$ \\
Austria & $100 \%$ & $95 \%$ & $97 \%$ & $97 \%$ & $95 \%$ \\
Azerbaijan & $83 \%$ & $81 \%$ & $80 \%$ & $81 \%$ & $79 \%$ \\
Bahamas & $91 \%$ & $92 \%$ & $93 \%$ & - & - \\
Bahrain & $82 \%$ & $81 \%$ & $78 \%$ & $79 \%$ & $74 \%$ \\
Belarus & $99 \%$ & $99 \%$ & $99 \%$ & $100 \%$ & $100 \%$ \\
Belgium & $100 \%$ & $98 \%$ & $98 \%$ & $98 \%$ & $96 \%$ \\
Belize & $100 \%$ & $100 \%$ & $100 \%$ & $100 \%$ & - \\
Bermuda & $91 \%$ & $91 \%$ & $87 \%$ & $94 \%$ & $92 \%$ \\
Bhutan & - & - & - & - & $71 \%$ \\
Bolivia & $67 \%$ & $69 \%$ & $66 \%$ & $68 \%$ & $68 \%$ \\
Bosnia & $100 \%$ & $100 \%$ & $100 \%$ & $99 \%$ & $100 \%$ \\
Botswana & $77 \%$ & $76 \%$ & $73 \%$ & $74 \%$ & - \\
Brazil & $97 \%$ & $98 \%$ & $98 \%$ & $96 \%$ & $97 \%$ \\
Brunei & $92 \%$ & $94 \%$ & $94 \%$ & $86 \%$ & $91 \%$ \\
Bulgaria & $97 \%$ & $93 \%$ & $95 \%$ & $93 \%$ & $93 \%$ \\
Cabo Verde & $92 \%$ & $85 \%$ & $81 \%$ & $86 \%$ & - \\
Canada & $100 \%$ & $99 \%$ & $100 \%$ & $100 \%$ & $98 \%$ \\
Chile & - & $97 \%$ & $97 \%$ & $95 \%$ & $95 \%$ \\
Colombia & $93 \%$ & $90 \%$ & $90 \%$ & $92 \%$ & $92 \%$ \\
Costa Rica & $94 \%$ & $96 \%$ & $97 \%$ & $96 \%$ & $96 \%$ \\
Croatia & $100 \%$ & $98 \%$ & $100 \%$ & $99 \%$ & $96 \%$ \\
& & & & &
\end{tabular}


medRxiv preprint doi: https://doi.org/10.1101/2021.08.12.21261978; this version posted August 14, 2021. The copyright holder for this preprint (which was not certified by peer review) is the author/funder, who has granted medRxiv a license to display the preprint in perpetuity.

It is made available under a CC-BY 4.0 International license.

\begin{tabular}{|c|c|c|c|c|c|}
\hline Cuba & $100 \%$ & $100 \%$ & $100 \%$ & $100 \%$ & $100 \%$ \\
\hline Cyprus & $76 \%$ & $68 \%$ & $74 \%$ & $69 \%$ & $72 \%$ \\
\hline Czechia & $100 \%$ & $97 \%$ & $100 \%$ & $100 \%$ & $99 \%$ \\
\hline Denmark & $100 \%$ & $98 \%$ & $98 \%$ & $100 \%$ & $96 \%$ \\
\hline Dominican Republic & $60 \%$ & $63 \%$ & $61 \%$ & $60 \%$ & $63 \%$ \\
\hline Ecuador & $79 \%$ & $79 \%$ & $80 \%$ & $80 \%$ & $81 \%$ \\
\hline Egypt & $100 \%$ & $100 \%$ & $98 \%$ & $99 \%$ & $100 \%$ \\
\hline El Salvador & $100 \%$ & $99 \%$ & $99 \%$ & $98 \%$ & $100 \%$ \\
\hline Estonia & $100 \%$ & $100 \%$ & $100 \%$ & $100 \%$ & $98 \%$ \\
\hline Eswatini & - & $45 \%$ & $44 \%$ & - & - \\
\hline Fiji & $99 \%$ & $100 \%$ & $97 \%$ & - & - \\
\hline Finland & $100 \%$ & $100 \%$ & $100 \%$ & $100 \%$ & $98 \%$ \\
\hline France & $100 \%$ & $100 \%$ & $100 \%$ & $100 \%$ & $99 \%$ \\
\hline French Guiana & $100 \%$ & $100 \%$ & $100 \%$ & $100 \%$ & $100 \%$ \\
\hline French Polynesia & $95 \%$ & $92 \%$ & $100 \%$ & $100 \%$ & $97 \%$ \\
\hline Georgia & $96 \%$ & $99 \%$ & $93 \%$ & $92 \%$ & $93 \%$ \\
\hline Germany & $100 \%$ & $99 \%$ & $100 \%$ & $100 \%$ & $98 \%$ \\
\hline Greece & $100 \%$ & $100 \%$ & $100 \%$ & $100 \%$ & $100 \%$ \\
\hline Greenland & $100 \%$ & $100 \%$ & $100 \%$ & $100 \%$ & $100 \%$ \\
\hline Grenada & $97 \%$ & $97 \%$ & $95 \%$ & $100 \%$ & $100 \%$ \\
\hline Guadeloupe & $92 \%$ & $99 \%$ & $95 \%$ & $96 \%$ & $100 \%$ \\
\hline Guatemala & $100 \%$ & $98 \%$ & $96 \%$ & $94 \%$ & $96 \%$ \\
\hline Guyana & $82 \%$ & $84 \%$ & $89 \%$ & - & - \\
\hline Hong Kong & $99 \%$ & $99 \%$ & $97 \%$ & $96 \%$ & $98 \%$ \\
\hline Hungary & $100 \%$ & $100 \%$ & $100 \%$ & $100 \%$ & $100 \%$ \\
\hline Iceland & $100 \%$ & $100 \%$ & $100 \%$ & $100 \%$ & $100 \%$ \\
\hline India & $68 \%$ & $69 \%$ & $69 \%$ & $73 \%$ & $79 \%$ \\
\hline Iran & $100 \%$ & $97 \%$ & $96 \%$ & $96 \%$ & $99 \%$ \\
\hline Iraq & - & $75 \%$ & $76 \%$ & $79 \%$ & $77 \%$ \\
\hline Ireland & $100 \%$ & $100 \%$ & $100 \%$ & $100 \%$ & $100 \%$ \\
\hline Israel & $100 \%$ & $100 \%$ & $100 \%$ & $97 \%$ & $98 \%$ \\
\hline Italy & $100 \%$ & $100 \%$ & $100 \%$ & $100 \%$ & $100 \%$ \\
\hline Ivory Coast & $21 \%$ & $21 \%$ & $20 \%$ & $21 \%$ & $24 \%$ \\
\hline Jamaica & $89 \%$ & $90 \%$ & $88 \%$ & $88 \%$ & $91 \%$ \\
\hline Japan & $100 \%$ & $100 \%$ & $100 \%$ & $100 \%$ & $100 \%$ \\
\hline Jordan & $91 \%$ & $92 \%$ & $88 \%$ & $84 \%$ & $88 \%$ \\
\hline Kazakhstan & $94 \%$ & $97 \%$ & $96 \%$ & $96 \%$ & $99 \%$ \\
\hline Kenya & $69 \%$ & $66 \%$ & $67 \%$ & $67 \%$ & $66 \%$ \\
\hline Kuwait & $70 \%$ & $68 \%$ & $66 \%$ & $62 \%$ & $64 \%$ \\
\hline Kyrgyzstan & $96 \%$ & $94 \%$ & $92 \%$ & $92 \%$ & $92 \%$ \\
\hline Latvia & $100 \%$ & $100 \%$ & $100 \%$ & $100 \%$ & $100 \%$ \\
\hline Lebanon & $86 \%$ & $82 \%$ & $84 \%$ & $79 \%$ & $78 \%$ \\
\hline Lesotho & $52 \%$ & $42 \%$ & $43 \%$ & $43 \%$ & $43 \%$ \\
\hline Lithuania & $100 \%$ & $100 \%$ & $100 \%$ & $100 \%$ & $100 \%$ \\
\hline Luxembourg & $100 \%$ & $99 \%$ & $100 \%$ & $100 \%$ & $100 \%$ \\
\hline Macao & $89 \%$ & $97 \%$ & $88 \%$ & $83 \%$ & $89 \%$ \\
\hline Malaysia & $100 \%$ & $100 \%$ & $100 \%$ & $100 \%$ & $100 \%$ \\
\hline
\end{tabular}


medRxiv preprint doi: https://doi.org/10.1101/2021.08.12.21261978; this version posted August 14, 2021. The copyright holder for this preprint (which was not certified by peer review) is the author/funder, who has granted medRxiv a license to display the preprint in perpetuity.

It is made available under a CC-BY 4.0 International license.

\begin{tabular}{|c|c|c|c|c|c|}
\hline Maldives & $84 \%$ & $89 \%$ & $88 \%$ & $85 \%$ & $71 \%$ \\
\hline Malta & $100 \%$ & $94 \%$ & $99 \%$ & $100 \%$ & $98 \%$ \\
\hline Martinique & $95 \%$ & $99 \%$ & $95 \%$ & $95 \%$ & $100 \%$ \\
\hline Mauritius & $100 \%$ & $100 \%$ & $99 \%$ & $100 \%$ & $100 \%$ \\
\hline Mayotte & $100 \%$ & $100 \%$ & $100 \%$ & $100 \%$ & $100 \%$ \\
\hline Mexico & $99 \%$ & $98 \%$ & $97 \%$ & $97 \%$ & $96 \%$ \\
\hline Moldova & $87 \%$ & $92 \%$ & $98 \%$ & $99 \%$ & $99 \%$ \\
\hline Monaco & $100 \%$ & $96 \%$ & $94 \%$ & $100 \%$ & $100 \%$ \\
\hline Mongolia & $81 \%$ & $77 \%$ & $74 \%$ & $79 \%$ & $76 \%$ \\
\hline Montenegro & $97 \%$ & $95 \%$ & $96 \%$ & $96 \%$ & $97 \%$ \\
\hline Myanmar & $53 \%$ & $50 \%$ & $53 \%$ & - & - \\
\hline Namibia & $99 \%$ & $94 \%$ & $97 \%$ & - & - \\
\hline Nepal & $51 \%$ & $65 \%$ & $36 \%$ & $51 \%$ & $91 \%$ \\
\hline Netherlands & $100 \%$ & $100 \%$ & $100 \%$ & $100 \%$ & $98 \%$ \\
\hline New Caledonia & $98 \%$ & $100 \%$ & $97 \%$ & $97 \%$ & $97 \%$ \\
\hline New Zealand & $100 \%$ & $98 \%$ & $100 \%$ & $99 \%$ & $100 \%$ \\
\hline Nicaragua & $81 \%$ & $80 \%$ & $81 \%$ & $79 \%$ & $81 \%$ \\
\hline North Macedonia & $94 \%$ & $93 \%$ & $92 \%$ & $88 \%$ & $90 \%$ \\
\hline Norway & $100 \%$ & $98 \%$ & $98 \%$ & $98 \%$ & $96 \%$ \\
\hline Oman & $63 \%$ & $73 \%$ & $73 \%$ & $74 \%$ & $71 \%$ \\
\hline Palestine & $76 \%$ & $76 \%$ & $73 \%$ & $74 \%$ & $74 \%$ \\
\hline Panama & $95 \%$ & $97 \%$ & $98 \%$ & $97 \%$ & $98 \%$ \\
\hline Paraguay & $89 \%$ & $93 \%$ & $85 \%$ & $90 \%$ & $92 \%$ \\
\hline Peru & - & - & $62 \%$ & $69 \%$ & $69 \%$ \\
\hline Philippines & $94 \%$ & $95 \%$ & $93 \%$ & $94 \%$ & $97 \%$ \\
\hline Poland & $100 \%$ & $100 \%$ & $100 \%$ & $100 \%$ & $100 \%$ \\
\hline Portugal & $100 \%$ & $100 \%$ & $99 \%$ & $100 \%$ & $98 \%$ \\
\hline Qatar & $71 \%$ & $69 \%$ & $65 \%$ & $64 \%$ & $55 \%$ \\
\hline Réunion & $91 \%$ & $90 \%$ & $88 \%$ & $92 \%$ & $91 \%$ \\
\hline Romania & $100 \%$ & $100 \%$ & $100 \%$ & $100 \%$ & $100 \%$ \\
\hline Russia & $100 \%$ & $100 \%$ & $100 \%$ & $100 \%$ & $99 \%$ \\
\hline Rwanda & - & - & - & - & $36 \%$ \\
\hline San Marino & $82 \%$ & $87 \%$ & $94 \%$ & $82 \%$ & $83 \%$ \\
\hline Saudi Arabia & - & $67 \%$ & $65 \%$ & $62 \%$ & - \\
\hline Serbia & $96 \%$ & $96 \%$ & $97 \%$ & $95 \%$ & $95 \%$ \\
\hline Seychelles & $97 \%$ & $100 \%$ & $99 \%$ & $100 \%$ & $100 \%$ \\
\hline Singapore & $91 \%$ & $89 \%$ & $90 \%$ & $88 \%$ & $86 \%$ \\
\hline Slovakia & $100 \%$ & $99 \%$ & $100 \%$ & $100 \%$ & $97 \%$ \\
\hline Slovenia & $100 \%$ & $99 \%$ & $100 \%$ & $99 \%$ & $98 \%$ \\
\hline South Africa & $86 \%$ & $86 \%$ & $84 \%$ & $84 \%$ & - \\
\hline South Korea & $100 \%$ & $98 \%$ & $96 \%$ & $98 \%$ & $93 \%$ \\
\hline Spain & $100 \%$ & $99 \%$ & $100 \%$ & $100 \%$ & $97 \%$ \\
\hline Sri Lanka & $100 \%$ & $98 \%$ & $100 \%$ & $100 \%$ & $100 \%$ \\
\hline Suriname & $89 \%$ & $86 \%$ & $84 \%$ & $88 \%$ & $91 \%$ \\
\hline Sweden & $100 \%$ & $99 \%$ & $100 \%$ & $99 \%$ & $96 \%$ \\
\hline Switzerland & $100 \%$ & $97 \%$ & $99 \%$ & $98 \%$ & $97 \%$ \\
\hline Taiwan & $97 \%$ & $100 \%$ & $97 \%$ & $96 \%$ & $97 \%$ \\
\hline
\end{tabular}




\begin{tabular}{lccccc} 
Tajikistan & $73 \%$ & $73 \%$ & $68 \%$ & $70 \%$ & $72 \%$ \\
Thailand & $100 \%$ & $99 \%$ & $94 \%$ & $93 \%$ & $97 \%$ \\
Trinidad and Tobago & $99 \%$ & $100 \%$ & $100 \%$ & $100 \%$ & - \\
Tunisia & $99 \%$ & $92 \%$ & $100 \%$ & $99 \%$ & $100 \%$ \\
Turkey & $95 \%$ & $97 \%$ & $97 \%$ & $96 \%$ & $96 \%$ \\
Ukraine & $85 \%$ & $85 \%$ & $84 \%$ & $86 \%$ & $85 \%$ \\
United Arab Emirates & $49 \%$ & $48 \%$ & $45 \%$ & $42 \%$ & - \\
United Kingdom & $100 \%$ & $99 \%$ & $100 \%$ & $99 \%$ & $96 \%$ \\
United States & $100 \%$ & $99 \%$ & $100 \%$ & $99 \%$ & $97 \%$ \\
Uruguay & $100 \%$ & $100 \%$ & $100 \%$ & $100 \%$ & $100 \%$ \\
Uzbekistan & $79 \%$ & $80 \%$ & $83 \%$ & $79 \%$ & $79 \%$ \\
Vietnam & - & - & - & $93 \%$ & $89 \%$ \\
Zambia & - & $34 \%$ & $36 \%$ & $34 \%$ & - \\
Zimbabwe & $33 \%$ & - & - & - & - \\
\hline
\end{tabular}

Table 1: Estimated Death Registration Completeness for 139 countries. "-" denotes no information on registered deaths.

For most of Africa, I was unable to obtain counts of registered deaths, and they thus have no estimate in table 1 or figure 1.A surprising and possibly false result is the completeness rate for Namibia, which I estimate at over about $95 \%$. This is probably due to an unreasonably low estimate for the annual number of expected deaths, which is given as 19.85 thousand deaths in (UNSD, 2021) and 19.25 thousand deaths in (GBD, 2020) for the year 2017. In fact, Namibia's own NSO in its' vital statistics report estimate the expected number of deaths for 2017 at over 25 thousand, thus obtaining a death registration completeness rate of $76 \%$.

Europe's vital registration is essentially complete across the board, with Andorra's completeness estimate stands out as the lowest in Europe, and in contrast to UNSD (2021) which estimate it at "90\% or more". This might be due to the long time since that estimate was derived (2005) or due to the difficulty in establishing a reliable estimate for the expected number of deaths in such a small country (about 78,000 residents), as suggested by United Nations (2019) not including estimates for countries with populations smaller than 900,000.

The countries of the Persian Gulf - Iran, Iraq (77\%), Kuwait (64\%), Qatar (55\%), Bahrain (74\%), United Arab Emirates (42\%), Oman (71\%) and Saudi Arabia () have relatively low estimated death completeness rates, with the exception of Iran (complete coverage). This is also in contrast to UNSD (2021) which estimate it as complete (Qatar, Saudi Arabia and the UAE) or close to 90\% (Bahrain, Kuwait and Oman) with roughly similar high completeness estimates from GBD (2020). This might be due to the large numbers and share of immigrant, temporary workers in these countries, which have a very different demographic composition than the rest of the population, especially in terms of age - which the expected death estimates from United Nations (2019) and GBD (2020) might not be taking into account properly.

While North America's vital registration is complete, several countries in South America have low completeness rates with Peru and Bolivia having the lowest estimated coverage in the analyzed time period. Although both UNSD (2021) and GBD (2020) contain fairly recent estimates of death completeness in Venezuela, I was unable to locate any figures for the registered number of deaths.

In terms of completeness through time, it seems to be fairly stable across the six years analyzed here for most countries. ${ }^{5}$ With the range $(\max -\min )$ higher than 5 percentage points for 40 countries. Additionally, testing for the existence of a trend in completion rate by estimating a simple linear regression of the completeness rate as a function of year, showed it to be statistically significant in only 13 countries.

\footnotetext{
${ }^{5}$ Nepal is a notable exception, with a significant drop in estimated completeness in 2017 and a large increase in 2019
} 


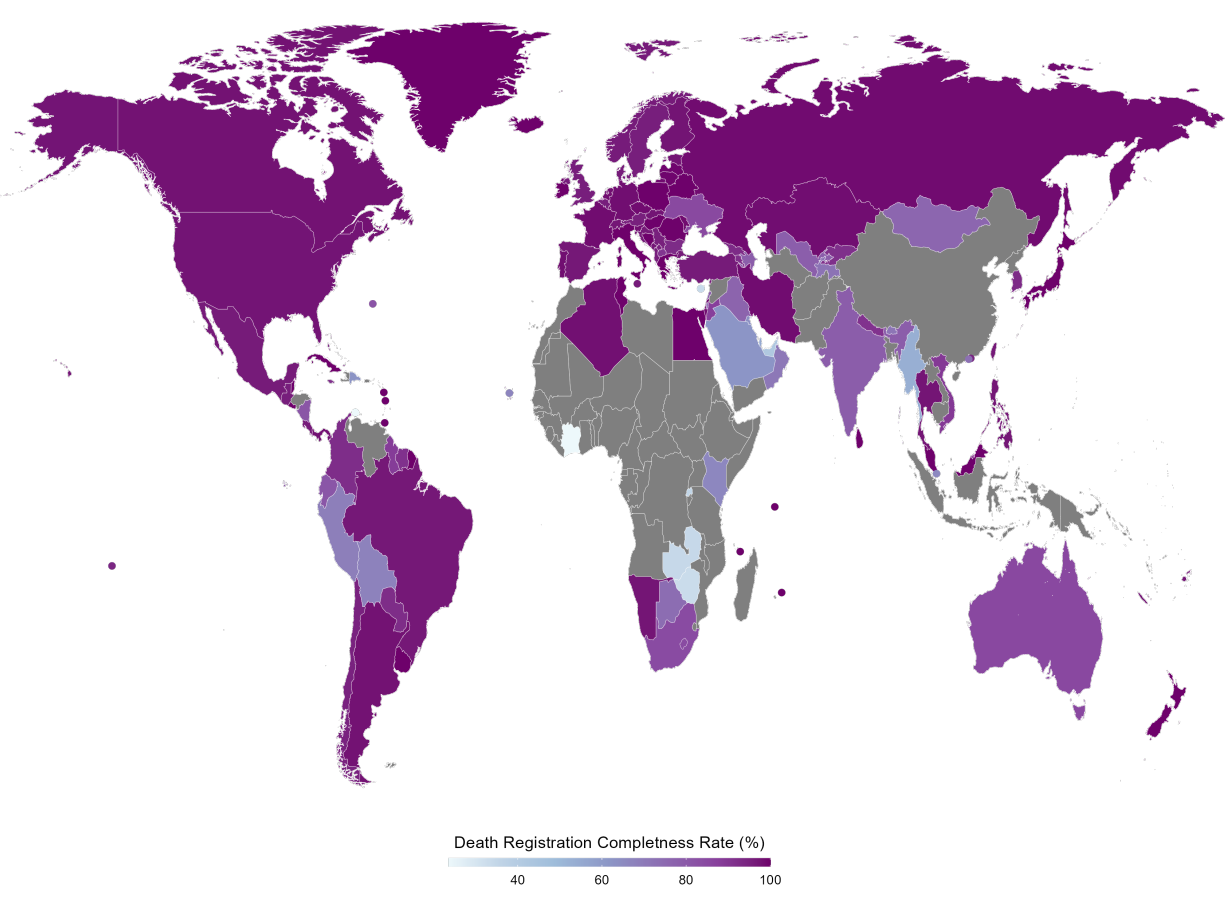

Figure 1: Completeness rate of death registration. Small countries and territories are shown with circles. Grey denotes no death registration data was located.

\section{Limitations}

This study has several limitations. For many countries I was unable to locate information on the number of deaths recorded by their vital registration systems. I have chosen to treat such instances as missing rather than at $0 \%$ completeness - since the data might exist but is it not shared. Some countries have completeness of death registration estimates as arises from surveys. These were not included as information on vital registration is essentially missing. I have tried my best to make sure that the mortality counts reported here are based on vital registration and not estimates derived from surveys, but it is possible that I have miss attributed some.

A significant limitation is the uncertainty embodied in the expected number of deaths, as derived from United Nations (2019) and GBD (2020). The expected number of deaths involves a complex estimation method that relies on many demographic variables as input. These might have large measurement errors or be the result of estimates themselves. Most likely, error in the expected number of deaths is correlated with a low completeness rate of vital registration, yet the direction of the error is unclear a-priori.

Some of the countries do not have a registered number of deaths for the entire period between 2015 to 2019. These are shown in table 2. Additionally, the territories of the Faroe Islands (Denmark), Gibraltar (UK) and the country of Liechtenstein, which have the number of registered deaths in Karlinsky and Kobak (2021) are not present, separately or as part of other countries in United Nations (2019) or GBD (2020) and so are excluded from this study.

\begin{tabular}{lccc}
\hline Country & First Year & Last Year & \# Years \\
\hline Bahamas & 2015 & 2017 & 3 \\
Belize & 2015 & 2018 & 4 \\
Bhutan & 2019 & 2019 & 1 \\
Botswana & 2015 & 2018 & 4 \\
Cabo Verde & 2015 & 2018 & 4 \\
Chile & 2016 & 2019 & 4
\end{tabular}




\begin{tabular}{llll} 
Eswatini & 2016 & 2017 & 2 \\
Fiji & 2015 & 2017 & 3 \\
Guyana & 2015 & 2017 & 3 \\
Iraq & 2016 & 2019 & 4 \\
Myanmar & 2015 & 2017 & 3 \\
Namibia & 2015 & 2017 & 3 \\
Peru & 2017 & 2019 & 3 \\
Rwanda & 2019 & 2019 & 1 \\
Saudi Arabia & 2016 & 2018 & 3 \\
South Africa & 2015 & 2018 & 4 \\
Trinidad and Tobago & 2015 & 2018 & 4 \\
United Arab Emirates & 2015 & 2018 & 4 \\
Vietnam & 2018 & 2019 & 2 \\
Zambia & 2016 & 2018 & 3 \\
Zimbabwe & 2015 & 2015 & 1 \\
\hline
\end{tabular}

Table 2: Description of countries with partial information

Some of the countries' 2019 estimate may be low due to incompleteness of the death registration process, resulting in a substantial drop in completeness in 2019, such as in Aruba and the Maldives. However, as these estimates are from 2021 reports, they may indicate a deficiency in the vital registration system with regards to timeliness or disruption in 2020-2021 due to COVID-19 (see section 5).

Reports on vital registration in the analyzed period may be forthcoming, such as Angola's report on vital registration in 2018, that is expected by the end of $2021 .{ }^{6}$ These will be added to the dataset on the public repository at https://github.com/akarlinsky/death_registration when published.

\section{$5 \quad$ Summary and Outlook}

In this study I have estimated and presented the latest completeness of death registration in 139from all over the globe. Completeness of death registration is a key feature and input into vital registration performance estimates, monitoring of SDGs and proper governance. There are other important properties of vital registration systems in general and death registration, in particular, that I did not analyze here. The timeliness of registration: i.e. the amount of time that passes between occurrence of death and it's registration; The share of deaths that are registered with cause-of-death information (WHO, 2021), sex and age (Mikkelsen et al., 2015); The share of deaths registered with proper attribution of cause of death and a low share of "garbage death cause codes"; etc. For example, while Egypt's death registration is complete, it has a high share of garbage codes (Iburg et al., 2020). These dimensions of vital registration should be the focus of more research, especially in countries which have achieved complete or close to complete coverage.

Several countries have recently published vital registration reports, yet this information has not reached global repositories maintained by UNSD and WHO. I recommend establishing a pipeline whereby the UNSD periodically checks with NSOs for the most recent reports on this, and update their global repositories accordingly.

The period I have analyzed here is six years prior to 2020, the year COVID-19 began to spread. The effect of COVID-19 and government mandated measures to combat it's spread on vital registration systems and the completeness rate is unclear. On the one hand, many vital registration systems "were either disrupted or discontinued" (Centre of Excellence for CRVS Systems, 2021) which might lower completeness rates in 2020

\footnotetext{
${ }^{6}$ https://www.ine.gov.ao/Arquivos/Geral/Calendario_publicacoes.pdf
} 
medRxiv preprint doi: https://doi.org/10.1101/2021.08.12.21261978; this version posted August 14, 2021. The copyright holder for this preprint (which was not certified by peer review) is the author/funder, who has granted medRxiv a license to display the preprint in

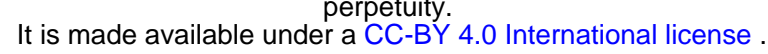

onward. On the other hand, the high excess mortality observed in Ecuador and Peru, where weekly mortality has stayed well above historical levels even at times of relative low numbers of reported COVID cases and deaths (Karlinsky and Kobak, 2021) might suggest an upward shift in completeness rates as well, with governments putting more resources into monitoring general and COVID mortality.

An additional dimension of vital registration and dissemination that should be emphasized is the frequency of the published data. Excess mortality estimates, crucial to our understanding of COVID-19 (Beaney et al., 2020; Islam et al., 2021; Karlinsky and Kobak, 2021; Adair et al., 2020) as well as future disasters and pandemics, requires high-frequency mortality data, such as weekly or monthly. High frequency data is crucial for monitoring the true extent of pandemics, epidemics and disasters. As for estimates, while annual number of registered deaths counts are better than no registration, their application to excess mortality estimates is limited since many of these events do not conform to annual timelines or last for a long duration. I thus recommend the WHO and UNSD encourage member states to publish high-frequency mortality data in the future, preferably by date of occurrence, just as they report periodical estimates of unemployment, prices, etc. 
medRxiv preprint doi: https://doi.org/10.1101/2021.08.12.21261978; this version posted August 14, 2021. The copyright holder for this preprint (which was not certified by peer review) is the author/funder, who has granted medRxiv a license to display the preprint in perpetuity.

It is made available under a CC-BY 4.0 International license.

\section{References}

Tim Adair and Alan D. Lopez. Estimating the completeness of death registration: An empirical method. PLOS ONE, 13(5):e0197047, May 2018. ISSN 1932-6203. doi: 10.1371/journal.pone.0197047. URL https://journals.plos.org/plosone/article?id=10.1371/journal.pone.0197047.

Tim Adair, Alan D. Lopez, and S Hudson. Approaches and methods for estimating excess deaths due to covid-19. Technical report, Bloomberg Philanthropies Data for Health Initiative, Civil Registration and Vital Statistics Improvement, University of Melbourne, 2020. URL https://crvsgateway.info/file/16908/4128.

South Africa Statistics South Africa. Mortality and causes of death in south africa: Findings from death notification 2018. Technical report, 2015 - 2018. URL http://www.statssa.gov.za/publications/P03093/ P030932018.pdf.

Namibia Statistics Agency. Namibia vital statistics report- registered births, deaths and marriages for the period 2016 - 2017. Technical report, 2015 - 2017. URL https://cms2.my.na/assets/documents/Namibia_Vital_ Statistics_Report.pdf.

Zambia Statistics Agency. Vital statistics report. Technical report, 2016 - 2018. URL https://www.zamstats . gov.zm/index.php/publications/category/8-demorgraphy.

Barrak Alahmad, Dawoud AlMekhled, Ayah Odeh, and Janvier Gasana. Disparities in Excess Deaths from the COVID-19 Pandemic Among Migrant Workers in Kuwait. medRxiv, page 2021.03.25.21254360, March 2021. doi: 10.1101/2021.03.25.21254360. URL https://www.medrxiv.org/content/10.1101/2021.03.25. $21254360 \mathrm{v} 1$.

Thomas Beaney, Jonathan M Clarke, Vageesh Jain, Amelia Kataria Golestaneh, Gemma Lyons, David Salman, and Azeem Majeed. Excess mortality: the gold standard in measuring the impact of COVID-19 worldwide? Journal of the Royal Society of Medicine, 113(9):329-334, 2020.

Botswana Statistics Botswana. Vital statistics report 2018. Technical report, 2015 - 2018. URL https://www . statsbots.org.bw/sites/default/files/publications/VItal\%20Statistics\%20Report\%202018.pdf.

D Bradshaw, RE Dorrington, R Laubscher, TA Moultrie, and P Groenewald. Tracking mortality in near to real time provides essential information about the impact of the COVID-19 pandemic in South Africa in 2020. South African Medical Journal, 2021.

Bhutan National Statistics Bureau. Vital statistics report of bhutan. Technical report, 2019. URL https: //www.nsb.gov.bt/vital-statistics-report/.

Centre of Excellence for CRVS Systems. Synthesis Brief: The impact of the COVID-19 pandemic on Africa: How civil registration and vital statistics systems supported an emergency response, 2021. URL https://crvssystems.ca/ synthesis-brief-impact-covid-19-pandemic-africa-how-civil-registration-and-vital-statistics-systems.

United Arab Emirates Federal Competitiveness and Statistics Centre. Births and deaths. Technical report, 2016 - 2017. URL https://fcsc.gov.ae/en-us/Pages/Statistics/Statistics-by-Subject.aspx\#/\% 3Fyear=\&folder=Demography\%20and\%20Social/Vital\%20Statistics/Births\%20and\%20Deaths\&subject= Demography\%20and\%20Social.

Dominican Republic Oficina Nacional de Estadistica. Anuario de estadisticas vitales 2020. Technical report, 2015 - 2019. URL https://www.one.gob.do/publicaciones/2021/anuario-de-estadisticas-vitales-2020/. 
medRxiv preprint doi: https://doi.org/10.1101/2021.08.12.21261978; this version posted August 14, 2021. The copyright holder for this preprint (which was not certified by peer review) is the author/funder, who has granted medRxiv a license to display the preprint in It is made available under a CC-BY 4.0 International license.

Cabo Verde Instituto Nacional de Estatistica. Estatisticas vitais: Nascimentos, Óbitos e casamentos, 2006-2018. Technical report, 2015 - 2018. URL https://ine.cv/publicacoes/ estatisticas-vitais-nascimentos-obitos-casamentos-2006-2018/.

New Caledonia Institut de la statistique et des études économiques. Bilan démographique 2019. Technical report, 2015 - 2019. URL https://www.isee.nc/component/phocadownload/category/110-demographie? download=2029: bilan-demographique-nouvelle-caledonie- 2019 .

Bahrain Information \& eGovernment Authority. Births and deaths 2019. Technical report, 2015 - 2019. URL https://www.data.gov.bh/en/ResourceCenter/DownloadFile?id=3472.

GBD. Global burden of 369 diseases and injuries in 204 countries and territories, 1990-2019: a systematic analysis for the Global Burden of Disease Study 2019. The Lancet, 396(10258):1204-1222, October 2020. ISSN 0140-6736, 1474-547X. doi: 10.1016/S0140-6736(20)30925-9. URL https://www.thelancet.com/journals/ lancet/article/PIIS0140-6736(20)30925-9/abstract.

India Office Of The Registrar General. Vital statistics of india based on thecivil registration system. Technical report, 2015 - 2019. URL https://censusindia.gov.in/2011-Common/Annual_Report.html.

Kim Moesgaard Iburg, Lene Mikkelsen, Tim Adair, and Alan D. Lopez. Are cause of death data fit for purpose? evidence from 20 countries at different levels of socio-economic development. PLOS ONE, 15(8):1-17, 082020. doi: 10.1371/journal.pone.0237539. URL https://doi.org/10.1371/journal.pone.0237539.

Nazrul Islam, Vladimir M Shkolnikov, Rolando J Acosta, Ilya Klimkin, Ichiro Kawachi, Rafael A Irizarry, Gianfranco Alicandro, Kamlesh Khunti, Tom Yates, Dmitri A Jdanov, Martin White, Sarah Lewington, and Ben Lacey. Excess deaths associated with covid-19 pandemic in 2020: age and sex disaggregated time series analysis in 29 high income countries. BMJ, 373:n1137, 2021.

Sarah Charlotte Johnson, Matthew Cunningham, Ilse N. Dippenaar, Fablina Sharara, Eve E. Wool, and Others. Public health utility of cause of death data: applying empirical algorithms to improve data quality. BMC Medical Informatics and Decision Making, 21(1):175, June 2021. ISSN 1472-6947. doi: 10.1186/s12911-021-01501-1. URL https://doi.org/10.1186/s12911-021-01501-1.

Ariel Karlinsky and Dmitry Kobak. Tracking excess mortality across countries during the COVID-19 pandemic with the World Mortality Dataset. eLife, 10:e69336, June 2021. ISSN 2050-084X. doi: 10.7554/eLife.69336. URL https://doi.org/10.7554/eLife.69336.

Samkelisiwe Khoza. 5073 deaths in 2017. 2018. URL http://new.observer.org.sz/details.php?id=7488.

Kenya KNBS. Statistical abstract 2020. Technical report, 2016 - 2019.

Lene Mikkelsen, David E. Phillips, Carla AbouZahr, Philip W. Setel, Don de Savigny, Rafael Lozano, and Alan D. Lopez. A global assessment of civil registration and vital statistics systems: monitoring data quality and progress. The Lancet, 386(10001):1395-1406, October 2015. ISSN 0140-6736, 1474547X. doi: 10.1016/S0140-6736(15)60171-4. URL https ://www . thelancet.com/journals/lancet/article/ PIIS0140-6736(15)60171-4/abstract.

Belize Statistical Institute of Belize. Abstract of statistics. Technical report, 2017 - 2019. URL http://sib. org.bz/publications/abstracts-of-statistics/.

Sri Lanka Department of Census and Statistics. Statistical abstract 2020. Technical report, 2015 - 2019. URL http://www.statistics.gov.1k/abstract2020/CHAP3. 
medRxiv preprint doi: https://doi.org/10.1101/2021.08.12.21261978; this version posted August 14, 2021. The copyright holder for this preprint (which was not certified by peer review) is the author/funder, who has granted medRxiv a license to display the preprint in It is made available under a CC-BY 4.0 International license.

Brunei Department of Economic Planning and Statistics. Brunei darussalam vital statistics 2019. Technical report, 2015 - 2019. URL http://www.deps.gov.bn/SitePages/Vital\%20Statistics.aspx.

Saudi Arabia Ministry of Health. Statistical yearbook. Technical report, 2015 - 2018. URL https://www.moh . gov.sa/en/Ministry/Statistics/book/Pages/default.aspx.

Nepal Department of National ID and Civil Registration. Annual progress report (fiscal year 2076/77). Technical report, 2015 - 2019. URL https://donidcr.gov.np/Files/ 84cac975-7a5c-43cc-9b40-9fe213332771newUserAdmin.pdf.

Bahamas Department of Statistics. Vital statistics provisional report. Technical report, 2015 - 2017a. URL https : //www.bahamas.gov.bs/wps/portal/public/reports\%20and\%20surveys/others/vital\%20statistics/ ! ut/p/b1/vZRLj6JAFEZ_kU2BxWsJiojKq6hCYEN4yFNFhAbh148z6WRWbc9iYtWqknPz3XtuUlRAeVRwjYYyj_ qyuUbn3- - AC20Z2M5BXErCWoFA4qDEyyxaqpB7Av4TAN8cCfypXwJV1yQo6CaDRaDRK5rbExaoW4Y6Uh72Ab9u9FFRnAE2sSN0jWx d549iNUkjGadeldubDaKilliOPdKb1YG1DV91wlicaFkqGLw8vBv0nj98AYPNj_ZEKXqrW6C_g1apehYAN_ RPAUMa2uZwo_4nx3zYrcBSmPABDp5pu2lzPqJrtyVnvDAMrI41d06gs2yA10MU9bSg5A2p6r1fJ1JPC0Kud5qTYSI1EZEnW90dp_ imQf30gCd8dSL878N1K4f 9XuqOCMr58jMnlA3xAAUJGoJdAZHieFQTKrXzuoXRarigoLPzY2R606YAWUoQeq1 JVVFMKzHqYxIBHI8 78v4Gpz4zxxiDb0RQUi5PIChLtIiqly101vSuivIOpXv63F63gVYRc6Ixf jsrw6up3BZu3AWbuAsDx26pUaTFF4emA22Vu6ges0a9 J4Ik27vs-c3u110kWI5VtavhqyXszBSUzyKKpmwT90uZNgfOKRka2_-e6VfYH1Qyw! !/dl4/d5/ L2dBISEvZOFBIS9nQSEh/.

Guyana Bureau of Statistics. Yearly and quarterly deaths by region and by sex. Technical report, 2015 - $2017 \mathrm{~b}$. URL https://statisticsguyana.gov.gy/subjects/demography-social-and-vital-statistics/.

Jordan Department of Statistics. Tables of births \& deaths. Technical report, 2016 - 2019. URL http://dosweb . dos.gov.jo/population/births-and-deaths/tables-birthsdeaths/.

Maldives National Bureau of Statistics. Statistical yearbook 2021. Technical report, 2015 - 2019a. URL http: //statisticsmaldives.gov.mv/yearbook/2021/wp-content/uploads/sites/8/2021/07/3.7.pdf.

Palestine Palestinian Central Bureau of Statistics. Statistical yearbook of palestine 2020. Technical report, 2015 - 2019b. URL https://www.pcbs.gov.ps/Downloads/book2545.pdf.

Suriname General Bureau of Statistics. Demographic data. Technical report, 2015 - 2019c. URL https: //statistics-suriname.org/en/population-statistics-2/.

Rwanda National Institute of Statistics of Rwanda. Rwanda vital statistics report 2020. Technical report, 2015 - 2019. URL https://www.statistics.gov.rw/statistical-publications/subject/vital-statistics.

Ivory Coast Ministry of the Interior. Annuaire statistique d'etat civil. Technical report, 2015 - 2018. URL http://www.depse.ci/fichiers_uploades/files/Annuaire\%20EC19_DESPSE-CI.pdf.

Vietnam General Statistics Office of Vietnam. Statistical yearbook of vietnam. Technical report, 2018 - 2019. URL https://www.gso.gov.vn/en/data-and-statistics/2020/09/statistical-yearbook-2019/.

Grenada Central Statistical Office. Live births and deaths, 2000 to 2020. Technical report, 2015 - 2019. URL https://stats.gov.gd/subjects/population-2/live-births-and-deaths-2000-to-2020/.

Algeria ONS. Demographie algerienne 2019. Technical report, 2015 - 2019. URL https://www.ons.dz/IMG/ pdf/demographie2019.pdf.

Iraq Central Statistical Organization. Health and vital statistics. Technical report, 2016 - 2019. URL http: //www.cosit.gov.iq/ar/2018-2019. 
medRxiv preprint doi: https://doi.org/10.1101/2021.08.12.21261978; this version posted August 14, 2021. The copyright holder for this preprint (which was not certified by peer review) is the author/funder, who has granted medRxiv a license to display the preprint in It is made available under a CC-BY 4.0 International license.

Myanmar Central Statistical Organization. Statistical yearbook 2019. Technical report, 2015 - $2017 . \quad$ URL https://www.csostat.gov.mm/PublicationAndRelease/StatisticalYearbook.

Fiji Bureau Of Statistics. Republic of fiji vital statistics report 2012-2017. Technical report, 2015 - 2017. URL https://www.statsfiji.gov.fj/statistics/social-statistics/vital-statistics-report.html.

Lesotho Bureau Of Statistics. Vital statistics (births \& deaths) 2019. Technical report, 2015 - 2019. URL http://www.bos.gov.ls/Publications.htm.

Rand Stoneburner and Fern Greenwell. Zimbabwe mortality trends report 1996-2015. 2017. URL https://www . sipotra.it/wp-content/uploads/2018/05/ZIMBABWE-MORTALITY-TRENDS-ANALYSIS-1996\% e2\%80\%932015.pdf.

Trinidad and Tobago Central Statistical Office. Demographic profile: Trinidad and tobago. Technical report, 2015 - 2018. URL https://cso.gov.tt/subjects/population-and-vital-statistics/vital-statistics/.

Turkey TUIK. Monthly death statistics. Technical report, 2015 - 2019. URL https://biruni.tuik.gov.tr/ medas $/$ ?kn=114\&locale=en.

UN. The sustainable development goals report. Technical report, 2020. URL https://unstats.un.org/sdgs/ report/2020/The-Sustainable-Development-Goals-Report-2020.pdf.

United Nations. World population prospects, 2019. URL https://population.un.org/wpp/Download/ Standard/Population/.

UNSD. Demographic yearbook 2021: Coverage of birth and death registration. Technical report, United Nations, Statistics Division, 2021. URL https://unstats.un.org/unsd/demographic-social/crvs/.

Javier Vargas-Herrera, Karim Pardo Ruiz, Gladys Garro Nuñez, Janet Miki Ohno, José Enrique Pérez-Lu, William Valdez Huarcaya, Benjamin Clapham, and Juan Cortez-Escalante. Resultados preliminares del fortalecimiento del sistema informático nacional de defunciones. Revista Peruana de Medicina Experimental y Salud Pública, 35:505-514, 2018.

WHO. World health statistics 2017: monitoring health for the sdgs, sustainable development goals. Technical report, 2017. URL http://apps . who.int/iris/bitstream/handle/10665/255336/9789241565486-eng.pdf? sequence $=1$.

WHO. Score for health data technical package: global report on health data systems and capacity. Technical report, 2021. URL https://cdn.who.int/media/docs/default-source/world-health-data-platform/ score/who_2021-01-31_global-report-score_tb_v2.pdf?sfvrsn=cf86a4fb_3\&download=true.

WHO. Completeness of cause-of-death data (\%), 2021. URL https://www.who.int/data/gho/data/ indicators/indicator-details/GHO/completeness-of-cause-of-death-data-(-). 